\author{
R. PLARRE, B. KRÜGER-CARSTENSEN
}

\title{
An attempt to reconstruct the natural and cultural history of the webbing clothes moth Tineola bisselliella Hummel (Lepidoptera: Tineidae)
}

\begin{abstract}
It is generally accepted that the natural habitats of most pest insects can be found outside the synanthropic environment in layers of leaf litter, under bark, as well as in rodent or bird nests. Indeed, most of the common pests have been reported as being facultative nidicolous. Therefore infestation of commodities by pest insects out of these reservoirs is one considerable possibility. However, the likelihood of a pest's occurrence and survival out-doors largely depends on its ecological potential and competitiveness against other species of the same ecological guild. Some pest species are rarely found in wild habitats, especially in those regions where they are not native and where they have been introduced by man. The fabric pest Tineola bisselliella serves as a good example. Most likely originating in Central or Southern Africa this insect was introduced into Europe probably not earlier than the late $18^{\text {th }}$ century. Being more tolerant to dry environments than other fabric pests its economical importance increased during the $20^{\text {th }}$ century when in-door climates changed because of central heating systems. Its occurrence in out-door natural habitats must be regarded as accidental. Reported founds of webbing clothes moth larvae in bird nests e.g. have been largely overstated in the literature. T. bisselliella should be regarded as an eusynanthropic species.
\end{abstract}

Key words: evolution, pest insect, phylogeny, synanthropy.

\section{BRIEF DESCRIPTION OF MORPHOLOGY AND PHYSIOLOGY}

The adult webbing clothes moth is a small moth that ranges in size from 4 to $9 \mathrm{~mm}$ and weighs up to $16 \mathrm{mg}$ (Kemper, 1935; Hannemann, 1977; Becker, 1983). The head and the rest of the body are covered with long hair. The rusty yellow head hairs point towards the front. The eyes are black. The mouth parts are reduced, the mandibles are rudimentary, the maxillary palps are very short or missing, and only the labial palps are apparent and well developed (Fig. 1). The wings are lanceolate and are fringed at their ends and rear edges. The forewings are yellowish, and the hind wings are grayishyellow. There are no striking markings on the wings. The wingspan ranges between 12 to $16 \mathrm{~mm}$. In flight, the hind wings are interlinked through a setaceous frenulum to the retinaculum of the forewings. The male moths are generally smaller than the female moths and have a few small tufts of hair on the last three abdominal segments. 
The larva, which reaches 7 to $9 \mathrm{~mm}$, has yellowish to yellow-whitish coloring (Hinton, 1956). The color of the food in the intestines often shines through the thin body covering. The head capsule is brown, sometimes with an almost black posterior border. Ocelli are missing. The back of the neck is light to yellowish-brown. The coxae are not fused through the median. The larvae create silk tubes in which they live and eat, which are securely interwoven with the substrate. Feces and substrate particles are integrated into the silk tubes.

Adult clothes moths do not take in any more nourishment. Only the larvae feed and are capable of metabolizing keratinous materials through the respective enzymes and special intestinal environment (Lotmar, 1942; Day, 1951a; 1951b; Powning et al., 1951; Hinton, 1956; Gerard, 2002; Hughes \& Vogler, 2006). The developmental time of the webbing clothes moth is related to the quality of its food, and is closely dependent upon temperature (Titschack, 1925; 1926). The moisture level also has a great impact on the length of the larval period. With good nourishment, a constant temperature of $28^{\circ} \mathrm{C}$ to $30^{\circ} \mathrm{C}$, and relatively high humidity, the total development from an egg to moth takes from about 45 to 70 days. Under poor developmental conditions, however, this development can take years. The number of larval stages correlates with the length of development and can lie between four and ten, as well as up to 40 stages (Titschack, 1927; Griswold, 1944).

The guild of keratophagous insects incorporates only few species, including some moth as well as hide and skin beetle species. Usually the relative humidity of a habitat directly corresponds to the substrate moisture content, which strongly influences successful infestations by the various species. However, in contrast to the guilds of xylophagous wood damaging or granivorous stored product-insects, for keratin feeding insects substrate moisture is not a limiting factor for intra-guild competition. Because of high levels of the protein keratin in wool and feathers, this diet is by far less hygroscopic than the cellulose in wood or the starch in grain. The moisture level of keratinous material is therefore more or less constantly low and not influenced by the relative humidity of the surrounding. Since textile pests are all capable of utilizing the dry substrate, the adaptive status varies therefore with their ability to physiologically conserve water. In comparison with e.g. the case-making clothes moths (Tinea pellionella L.) or carpet beetles (Anthrenus spp.), the webbing clothes moth is more tolerant to low relative humidity of up to $20 \%$ (Griswold, 1944; Hinton, 1956), and due to changing living climates to drier homes, the importance of this pest has been constantly increasing. It has widely replaced the case-making clothes moth (Weidner, 1970; Klausnitzer, 1993), which used to be prevalent in homes but requires lower temperatures and higher levels of humidity (Cheema, 1956). Webbing and case-making clothes moths can, however, co-exist (Key \& Common, 1959), when locally suitable microhabitats allow for different levels of humidity. The feeding tube of the webbing clothes moth which is tight to the substrate may serve better in the aspect of preventing water loss than the portable sacks by other tineid moths. 


\section{Geographic origin, global spread, and current habitats}

The biogeographic origin of T. bisselliella is basically still undecided, but is conjectured to be in South to Central Africa (Hinton, 1956; Weidner, 1970; Robinson \& Nielsen, 1993). Webbing clothes moths are not autochthon to Europe, as they were first explicitly mentioned there not before the $19^{\text {th }}$ century. Neither Linné nor Frabricius described them in their systematic works, and in a report about controlling moths in textiles by Réaumur to the Paris Academy in 1728, the webbing clothes moth in its true sense was not mentioned (Weidner, 1970). Thus one can rightly assume that $T$. bisselliella arrived relatively late in Europe, possibly introduced accidentally with the trade of natural produce and game trophies from Africa, and later spread throughout the world. Mentioning of "clothes moths" in the classic literature of the Antiquities, e.g. in Aristotle and Aristophanes (Beavis, 1988), or in the Bible (Bodenheimer, 1960) clearly does not refer to T. bisselliella. The decisive evidence for this assumption comes from a description of the destructive larvae, which are described to live in a "mobile enclosure" of a sack. This is not the case for T. bisselliella, as the larvae of this species live in immobile silk tubes, which are securely woven into the substrate (see above). Portable woven sacks are created, for instance, by Tinea spp. and Monopis spp. In the citations from the Antiquities, they are thus more likely describing an entire group of diverse facultative synanthropic keratophagous moth species (Robinson, 1979).

Although T. bisselliella today is more or less globally distributed, it is a neozoon in most parts of the world. Its cosmopolitan propagation is strictly synanthropic and it is one of the most economically significant textile pests (Kemper, 1935; Becker, 1960; 1983).

New species, introduced into new environments usually do not outcompete naturally occurring species within their ecological guild because the latter are ecologically well adapted to their habitats. However, factors may exist in the close vicinity of humans which favour or even enhance the establishment of introduced species over native species.

Reports of damages caused by T. bisselliella to wool, feathers, hair, and fur, as well as clothing and basic commodities made from these materials inside households and museums are numerous (Hinton, 1956; Hammers, 1987; Parker, 1990; Pinniger, 1994; Rajendran \& Parveen, 2005). Reports in the literature regarding the presence of webbing clothes moths in natural habitats away from human housings are, in contrast, rare and confusing. For example, in his summary of bibliographies on nidicolous insects Hicks (1959) lists 15 references to T. bisselliella findings in bird nests. Thus, in secondary and tertiary literature, it is often listed as a common species in bird nests (Niethammer, 1937; Uhlmann, 1937/1938; Hinton, 1956, Petersen, 1969; Hannemann, 1977; Klausnitzer, 1988; Pinniger, 2001; Cox \& Pinniger, 2007). Our own studies of the listed original references, however, do not allow for this general conclusion. First one notices duplications of citations as well as generalized faunistic reports from secondary literature without specified data. This limits the number of works reporting the presence of webbing clothes moths in bird nests to only six original references. In addition, the abundances of individuals in these finding are very small. According to Kemper (1938), while $63 \%$ of the 64 nests studied (nests of house and tree field sparrows, 
great and blue tits, barn swallows, house martins, and "city pigeons") contained moth larvae or moths, only $10 \%$ of them contained webbing clothes moths with a total of 24 individual specimens. The largest portion (95\%) housed the so-called "case-bearing moths" (s. below) with over 2000 individual specimens. Furthermore, after a yearlong study on numerous common swift nests, Büttiger (1944) also reported on only finding one moth and one pupa. According to Boyd (1936), while webbing clothes moths, casebearing clothes moths, and other moths are commonly found in swallow nests, there is no differentiation as to what species are found, so that the actual percentage of $T$. bisselliella remains unclear. In their studies of nests of various species of birds, Woodroffe \& Southgate (1951/1952) and Woodroffe (1953) only found a very small quantity of webbing clothes moths in only $3 \%$ of the nests studied, exclusively in house sparrow nests. Herfs (1936) also does not include any absolute data, but does report on a very small number of webbing clothes moths compared to the high number of case-bearing clothes moths. In addition, an updated literature search revealed, that Weidner (1961) found only one webbing clothes moth larva in one out of six pigeon nests. The larvae of case-making clothes moth (T. pellionella) and the brown house moth (Hofmanophila pseudospretella Stainton), as well as the "pigeon moth" (Tinea columbariella Wocke), all "case-bearing" moth larvae, were more frequently found. On the other hand, indirect negative reports on T. bisselliella exist: Nordberg (1936) did not find any webbing clothes moths in a total of 422 nests of various bird species, while he did find large numbers of case-making clothes moths, brown house moths, and brown-dotted clothes moth (Niditinea fuscipunctella Haworth), and Hinton (1956) never found any webbing clothes moth in bird nests. Similarly, the webbing clothes moth is not listed in the results of the faunistic investigations by Green (1980) and Krall (1981).

T. bisselliella must then be considered to be an exception and a seldom to very seldom occurrence in bird nest biocenoses. The females' very poor flight ability (Hinton, 1956), as well as the strong competition from other species in natural habitats may be the causes. Other tineids, especially the case-making clothes moth and the "pigeon moth", as well as the Oecophoridae brown house moth and several species of Anthrenus and Attagenus dermestid beetles are the most common keratinophagous nidicolous insects found in mild climate zones. In tropical regions of Asia, away from human settlements, the known bird nest inhabitants are not webbing clothes moths, but rather other kinds of tineids (Robinson, 1988a).

The seldom occurrence of webbing clothes moths as nidicolous insects in birds nests is thus certainly tied to secondary infestation from housing or businesses in urban spaces, as for all of the positive instances listed above the few nests in which webbing clothes moths were found had direct contact to human living quarters. Infestation the other way around, from the bird nest to human dwellings, is unlikely - the economically relevant new infestations by webbing clothes moths do not usually occur through natural habitats, but rather through the displacement and receipt of infested materials (Kemper, 1935).

These general and rather theoretical considerations of $T$. bisselliella being a eusynanthropic species are supported by out-door pheromone trapping results carried out in 
the year 2008/2009. In and near Berlin (Germany) several trapping locations outside houses were set up inside and outside the city limits. Trapping was performed from August to July with sticky traps containing a pheromone lure for T. bisselliella provided by Insects Limited (Indianapolis, USA). Traps were checked and lures were changed
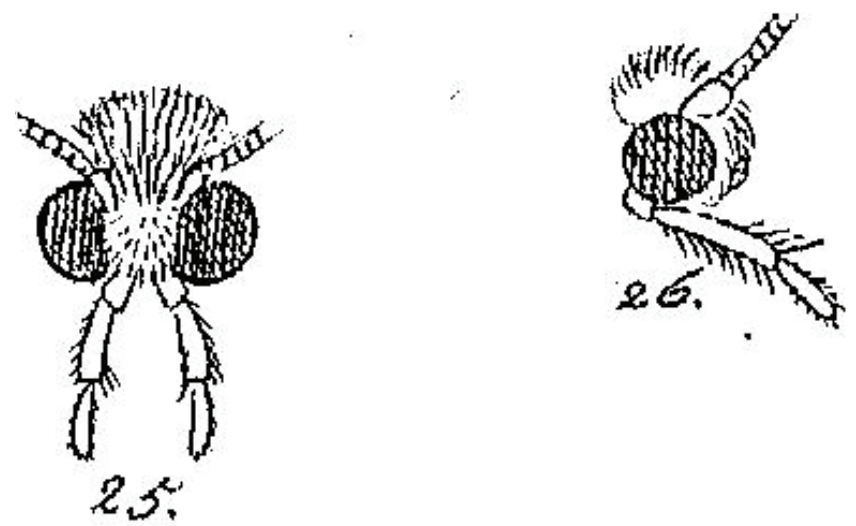

Fig. 1 - Original drawings by Herrich-Schäffer (1853) of systematic details regarding Tineola bisselliella labial palps.

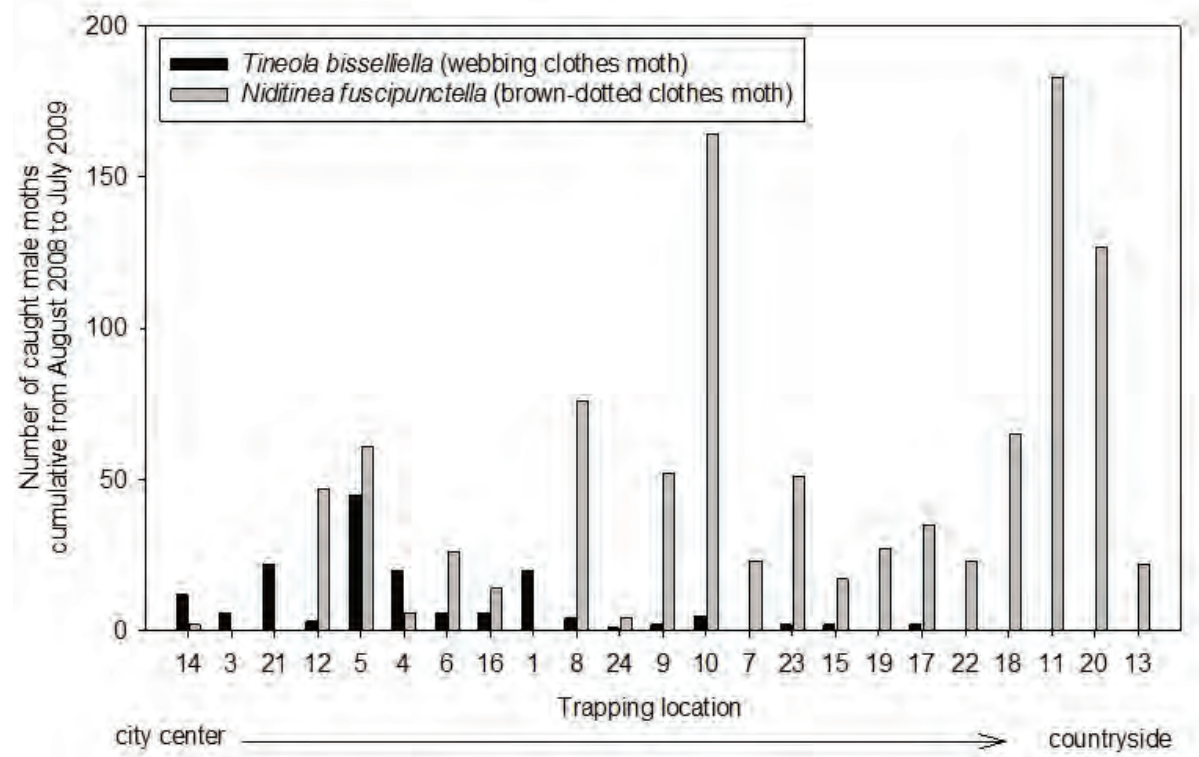

Fig. 2 - Trap captures of webbing clothes moths and brown-dotted clothes moths at different trapping locations in and around Berlin, Germany, sorted from city center to countryside. Numbers of trapped male moths are cumulative for 1 year. 
on a biweekly basis. Fig. 2 shows catch data arranged from city center to country side. The further away from the city the fewer was the number of $T$. bisselliella captures up to total absence of this species in the country side. Interestingly, another tineid moth, the brown-dotted clothes moth ( $N$. fuscipunctella), was also caught in high amounts. It is known that males of this species are attracted to alcohol compounds (Hwang et $a l .$, 1978), and most likely they were lured into the trap by the webbing clothes moth pheromone's solvent. The brown-dotted clothes moth is a well documented and typical species from bird nests in Central Europe (see above) and frequently trapped with alcohol based lures (Trematerra \& Fiorilli, 1999). Trap catches of N. fuscipunctella, however, were reciprocal to those of $T$. bisselliella with highest numbers in the country side.

\section{Biosystematics and annotations on phylogenesis}

The first scientific description of the webbing clothes moth (in its classic sense) as Tinea bisselliella comes from Hummel in the year 1823 (Herrick \& Griswold, 1933). Zeller (1852) produced the first detailed description on the morphology and dispersion. Due to morphological characteristics, including the lack of maxillary palps and a reduced glossa (Fig. 1), Herrich-Schäffer (1853) established the genus Tineola with Tineola bisselliella and three additional species, which were later reallocated to different taxa, due to the characteristics of the genitals. Currently, but with reservations, only one other species, Tineola anaphecola Gozmány, is included in this genus (Gozmány \& Vári, 1973) but the authors do not explicitly specify whether or not both species truly form a sister clade. Due to newer genital morphological traits (Petersen, 1957) as well as biochemical traits (Cook et al., 1997), Tineola spp. likely should be included within the "Tinea-group" and should no longer be considered to be the sister-taxon to the "Tinea- and Monopis-group" (Hannemann, 1977) (Fig. 3). Due to the unclear status of $T$. anaphecola, one could consider other Tinea species as potentially the most closely related taxa to $T$. bisselliella.

Tineola anaphecola is so far known to exist only in tropic West Africa, where it was found nidicolously and entomophagously in caterpillar nests. As it has frequently been conjectured, it is possible that the natural origin of $T$. bisselliella can also be found in the same region (see above), where it may have had an entomo-nidicolous lifestyle, under mummified conditions or possibly also living on cadavers. Their presence has been proven both in nests of social hymenoptera (four separate cases) and on a cadaver (singular incident) (Linsley, 1944; Weidner, 1952 cited in Petersen, 1963).

Feeding behavior among Tineidae is very divers and can best be described as detrito-mycetophag (Robinson \& Nielsen, 1993, Davis \& Robinson, 1999). Taking the phenogram by Cook et al. (1997) (Fig. 3 right side), which is based on similarities of cuticular fatty acids, as a blueprint for phylogenetic relationships among the Tineidae, and incorporating feeding ecology into this phenogram, the following evolutionary scenario regarding food exploitation could occur (Fig. 4): The common ancestor of the Tineidae, including Hieroxestinae (with Amphixystis ssp.), Scardiinae (with Morophaga ssp.), Nemapogoninae (with Nemapogon ssp.) and Tineinae (with Monopis spp. Tineola spp. and Tinea spp.) was feeding more or less on rotten plant detritus 


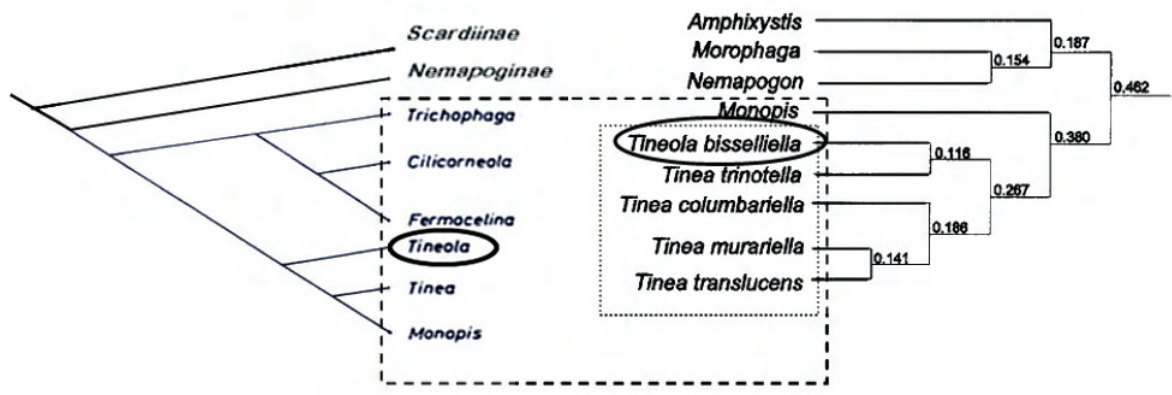

Fig. 3 - Comparative relationships of Tineola bisselliella within the Tineidae which are comprised of the Tineinae (dashed box) + Nemapoginae + Scardiinae, based upon Hannemann (1977) according to morphological genital traits (left) and upon Cook et al. (1997) according to data analyses of cuticular fatty acid percentages "centroid cluster analysis" (right).

(Note on the right phenogram: Morophaga represents the Scardiinae and Amphixystis stands for the Hieroxestinae, which Hannemann (1977) did not discuss).

Amphixystis ssp.

Morophaga. ssp.

Nemapogon ssp.

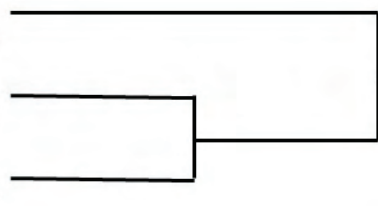

fungivorous
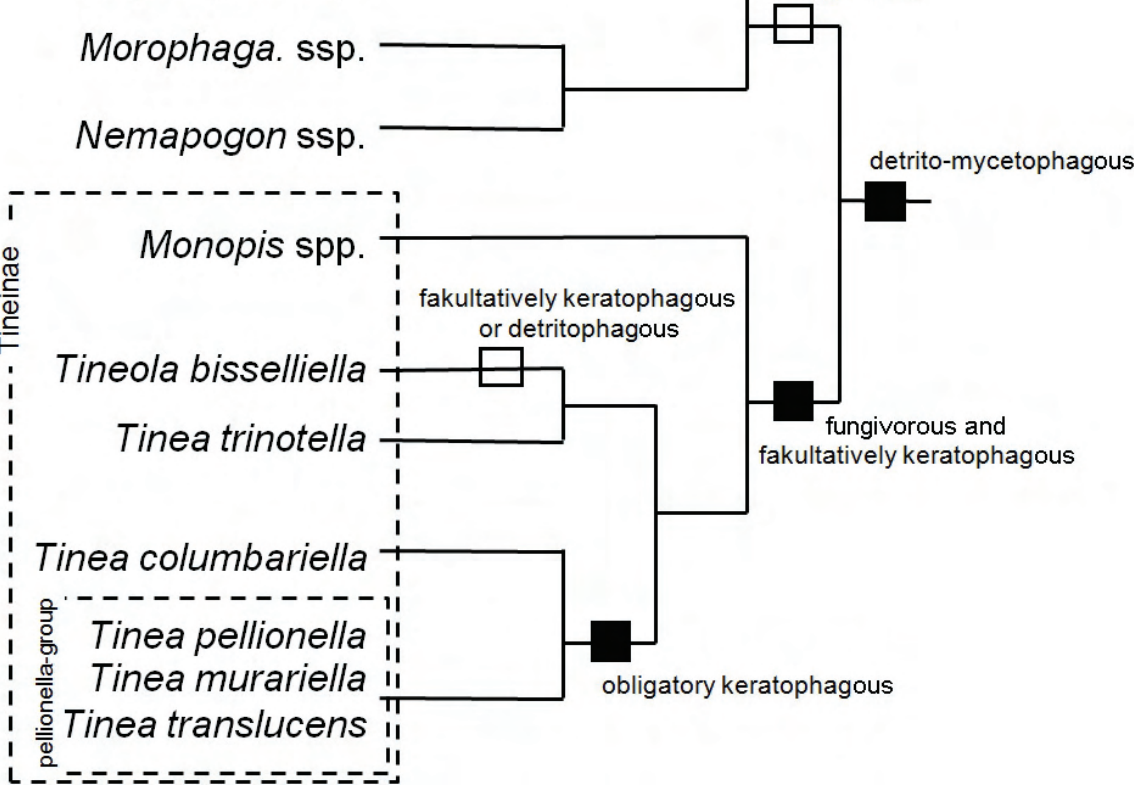

Fig. 4 - Relationship among the Tineidae (according to Cook et al. (1997), see also Fig. 3), with added feeding ecology. 
which includes facultative feeding on various fungi and lichen (Hannemann, 1977). For Amphixystis ssp., Morophaga ssp. and Nemapogon ssp. decomposing fungi are still the preferred food source (Petersen, 1969). The common ancestor of the Tineinae (Fig. 4 large dotted box) also fed on fungi but was able to partly consume keratin as well, maybe through the enzymatic synergism of keratinases by fungi. Finally, in the Tineinae some taxa like the "pellionella-group" (Fig. 4 small dotted box) specialized and shifted obligatory on keratinous food, while others including T. bisselliella (which is not part of the "pellionella-group") remained oligophagous. Interestingly, among all described subtaxa in the Tineinae, the specialized "pellionella-group" hosts the majority of species being known as pests on textiles (Robinson, 1988b). Compared to those, T. bisselliella is not restricted to food of animal origin. It can successfully live not only on cholesterol but also on pure phytosterol containing food sources (Becker, 1980; Sellenschlo, 1990; Stejskal \& Horak, 1999), whereas T. pellionella e.g. cannot survive on botanical materials (Ishii \& Kawahara, 1966).

Other behavioural characteristics in tineid moths, like the differences in constructing frass-tunnel or making cases, certainly reflect different strategies to prevent desiccation by minimizing water loss because of shelter tubes. However, case building and their structures are by no means consistent within phylogenetics (Davis \& Robinson, 1999).

\section{CONCLUSION}

The summary of autecological, behavioral, and historical data in combination with critically analyzed published faunistic records make the webbing clothes moth appear to be a true synanthropic species in most parts of the world. Its local spread is favored only by trade and exchange of infested commodities. New infestations from natural reservoirs are most unlikely. Preventive pest control strategies should therefore focus on proper quarantine measures.

\section{REFERENCES}

Beavis I.C., 1988 - Insects and other invertebrates in classical antiquity. Alden Press, Oxford.

Becker G., 1960 - Biologische Untersuchungen an Textilien. In: Siebel, E., Sommer, H. (Eds.), Handbuch der Werkstoffprüfung Band, 5: 971-1007.

Becker G., 1980 - Fördernde Ernährungswirkung von Pflanzenstoffen auf KleidermottenRaupen. Material und Organismen, 15: 1-8.

BECKER G., 1983 - Materialschädlinge. In: Heinze, K. (Ed.), Leitfaden der Schädlingsbekämpfung, Band IV: Vorrats- und Materialschädlinge. Wissenschaftliche Verlagsgesellschaft, Stuttgart, 269-336.

BodenHeIMER F.S., 1960 - Animal and man in bible lands. Brill, Leiden.

Boyd A.W., 1936 - Report on the swallow enquiry, 1935. British Birds, 30: 98-116.

Büttiker W., 1944 - Die Parasiten und Nestgäste des Mauerseglers (Micropus apus L.). Der

Ornithologische Beobachter, 41: 25-35. 
Cheema P.S., 1956 - Studies on the binomics of the case-bearing clothes moth, Tinea pellionella (L.). Bulletin of Entomological Research, 47: 167-182.

Cook M.A., Harwood L.M., Robinson G. S., 1997 - Long-chain fatty acids and systematics of the Tineidae. Biochemical Systematics and Ecology, 25: 603-610.

Cox P.D., Pinniger D.B., 2007 - Biology, behaviour and environmental sustainable control of Tineola bisselliella (Hummel) (Lepidoptera: Tineidae). Journal of Stored Products Research, 43: 2-32.

Davis D.R., Robinson G.S., 1999 - The Tineoidea and Gracillarioidea. In: Kristensen N. P., Beutel R. (Eds.), Lepidoptera, Moths and Butterflies. 1. Evolution Systematics and Biogeography, Hanbook of Zoology 4, De Gruyter, Berlin, 91-117.

Day M.F., 1951a - Studies on the digestion of wool by insects. I. Microscopy of digestion of wool by clothes moth larvae Tineola bisselliella (Humm.). Australian Journal of Scientific Research Series B, Biological Sciences, 4: 42-48.

DAY M.F., 1951b - Studies on the digestion of wool by insects III. A comparison between the tracheation of the midgut of Tineola larvae and that of other insect tissues. Australian Journal of Scientific Research Series B, Biological Sciences, 4: 64-74.

GERARD P.J., 2002 - The digestive system of the keratin-feeding larvae of Hofmannophila pseudospretella (Lepidoptera: Oecophoridae). New Zealand Journal of Zoology, 29: 15-22.

GozmÁny L.A., VÁRI L., 1973 - The Tineidae of the Ethopian Region. Transvaal Museum Memoirs No. 18. Heer Printing, Pretoria.

Green D.B., 1980 - The fauna of a Lancashire deep-pit poultry house. The Entomologist's Monthly Magazine, 116: 13-15.

Griswold G.H., 1944 - Studies on the biology of the webbing clothes moth (Tineola bisselliella Hum.). Cornell University Agricultural Experiment Station Memoir, 262: 1-59.

Hammers J., 1987 - Neue Beiträge zum Abbau von Wolle durch Motten- und Käferlarven. Schriftenreihe des Deutschen Wollforschungsinstitutes, 100: 1-92.

Hannemann H.J., 1977 - Kleinschmetterlinge oder Microlepidoptera III. Federmotten (Pterophoridae) Gespinnstmotten (Yponomeutidae), Echte Motten (Tineidae). Die Tierwelt Deutschlands 63. Gutav Fischer, Jena.

Herfs A., 1936 - Ökologisch-physiologische Studien an Anthrenus fasciatus Herbst. Zoologica 34, Heft 90.

Herrich-Schäffer G.A.W., 1853 - Systematische Bearbeitung der Schmetterlinge von Europa, zugleich als Text, Revision und Supplement zu Jakob Hübner`s Sammlung europäischer Schmetterlinge. Fünfter Band, die Schaben und Federmotten. Manz, Regensburg.

Herrick G.W., Griswold G.H., 1933 - On the scientific name of the webbing clothes moth. Science, 1999: 391-392.

Hicks E.A., 1959 - Check-list and bibliography on the occurrence of insects in birds' nests. Iowa State College Press, Ames.

Hinton H.E., 1956 - The larvae of the species of Tineidae of economic importance. Bulletin of Entomological Research, 47: 251-346.

Hughes J., Vogler A.P., 2006 - Gene expression in the gut of keratin-feeding cothes moths (Tineola) and keratin beetles (Trox) revealed by substarcted cDNA libraries. Insect Biochemistry and Molecular Biology, 36: 584-592.

Hwang Y.S., Mulla M.S., Axelrod H., 1978 - Attractants for synanthropic flies: ethanol as attractant for Fannia canicularis and other pest flies in poultry ranches. J. Chem. Ecol., 4: 463-470.

IshiI S., KaWAhara S., 1966 - Utilization of sterols in clothes moth, Tinea pellionella and Tineola bisselliella. Botyu-Kagaku, 31: 153-157. 
KemPer H., 1935 - Die Pelz- und Textilschädlinge und Ihre Bekämpfung. Hygienische Zoologie, Monographien zur Biologie und Bekämpfung der Gesundheits- und Wohnungs-Schädlinge 7.

Kemper H., 1938 - Hausschädlinge als Bewohner von Vogelnestern. Zeitschrift für Hygienische Zoologie und Schädlingsbekämpfung, 30: 227-236, 269-274, 291-297.

Key K.H.L., Common I.F.B., 1959 - Observation on the ecology of the clothes moths Tineola bisselliella (HUMM.) and Tinea pellionella L. in a bulk wool store. Australian Journal of Zoology, 7: 39-77.

Klausnitzer B., 1988 - Verstädterung von Tieren. Die Neue Brehm Bücherei 579.

Klausnitzer B., 1993 - Ökologie der Großstadtfauna. Gustav Fischer, Jena.

KRALL S., 1981 - Ökofaunistische Untersuchungen der Insekten in Nestern der Stadttaube (Columba livia domestica L.) unter besonderer Berücksichtigung schädlicher und lästiger Arten. Entomologische Mitteilungen Zoologisches Museum Hamburg, 7: 29-44.

LinsLEY E.G., 1944 - Natural sources, habitats, and reservoirs of insects associated with stored food products. Hilgardia, 16: 187-224.

Lotmar R., 1942 - Das Mitteldarmepithel von Tineola bisselliella (Kleidermotte) während der Metamorphose. Mitteilungen der Schweizerischen Entomologischen Gesellschaft, 18: 445455.

Niethammer G., 1937 - Handbuch der Deutschen Vogelkunde Band 1: Passeres. Akademische Verlagsgesellschaft, Leipzig.

Nordberg S., 1936 - Biologisch-ökologische Untersuchungen über die Vogelnidicolen. Acta Zoologica Fennica, 21: 1-168.

PARKer T.A., 1990 - Clothes moths. In: Mallis, A. (Ed.), Handbook of Pest Control. Franzak and Foster Company, Cleveland, 347-375.

Petersen G., 1957 - Die Genitalien der paläartischen Tineiden. Beiträge zur Entomologie, 7: 55176.

Petersen G., 1963 - Tineiden als Bestandteil der Nidicolenfauna. Beiträge zur Entomologie, 13: 411-427.

Petersen G., 1969 - Beiträge zur Insekten-Fauna der DDR: Lepidoptera - Tineidae. Beiträge zur Entomologie, 19: 311-388.

Pinniger D.B., 1994 - Insect pests in museums. - Archetype Press, London.

Pinniger D.B., 2001 - Pest management in Museums Archives and Historic Houses. Archetype Press, London.

Powning R.F., Day M.F., IrZYKIEwicz H., 1951 - Studies on the digestion of wool by insects. II. The properties of some insect proteinases. Australian Journal of Scientific Research Series B, Biological Sciences, 4: 49-63.

RajendRan S., PARVEen K.M.H., 2005 - Insect infestation in stored animal products. Journal Stored Products Research, 41: 1-30.

Robinson G.S., 1979 - Clothes-moths of the Tinea pellionella complex: a revision of the world's species (Lepidoptera: Tineidae). Bulletin of the British Museum (Natural History), Entomological Series, 38: 57-128.

Robinson G.S., 1988a - Keratophagous moths in tropical forests - investigations using artifical birds' nests. The Entomologist, 107: 34-45.

RoBinson G.S., 1988b - A phylogeny of the Tineoidea (Lepidoptera). Entomologica Scandinavica, 19: 117-129.

Robinson G.S., NielSEN E.S., 1993 - Tineid genera of Australia (Lepidoptera). Monographs on Australian Lepidoptera, Volume 2. CSIRO Publikations, Melbourne.

Sellenschlo U., 1990 - Kleidermotten in Backwaren. Der Praktische Schädlingsbekämpfer 3/90, $34-35$ 
Stejskal V., Horak P., 1999 - Webbing clothes moth, Tineola bisselliella (Hum.), causing serious damage to Lactuca sativa and other plant seeds. Anzeiger für Schädlingskunde, 72: 87-88.

Tiтsснаск E., 1925 - Untersuchungen über den Temperatureinfluß auf die Kleidermotte (Tineola bisselliella Hum.). Zeitschrift für wissenschaftliche Zoologie, 124: 213-251.

Tiтsснаск E., 1926 - Untersuchungen über das Wachstum, den Nahrungsverbrauch und die Eierzeugung. II. Tineola bisselliella Hum. Gleichzeitig ein Beitrag zur Klärung der Insektenhäutung. Zeitschrift für wissenschaftliche Zoologie, 128: 509-569.

Tiтschaк E., 1927 - Die Bedeutung der Temperatur für Haus- und Speicherschädlinge. Mitteilungen der Gesellschaft für Vorratsschutz, 3: 12-14.

Trematerra P., Fiorilli F., 1999 - Occurrence of Arthropods in a Central Italy feed-mill. Anzeiger für Schädlingskunde, 72: 158-163.

Uhlmann E., 1937/1938 - Unsere Material- und Vorratsschädlinge in ihrer Beziehung zum Freilandleben. Mitteilungen der Gesellschaft für Vorratsschutz 13 and 14, 57-60 and 3-10.

WeIDNER H., 1961 - Die Niststätten verwilderter Tauben als Reservoire für Ungezieferplagen. Stadthygiene, 12: 91-94.

Weidner H., 1970 - Die Kleidermotte, Tineola bisselliella (Hummel, 1823). Der Praktische Schädlingsbekämpfer, 22: 70-76.

Woodroffe G.E., 1953 - An ecological study of the insects and mites in the nests of certain birds in Britain. Bulletin of Entomological Research, 44: 739-772.

Woodroffe G.E., Southgate B.J., 1951/1952 - Birds' nests as a source of domestic pests. Proceedings of the Zoological Sciety of London, 121: 55-62.

ZelLer P.C., 1852 - Die Schaben mit langen Kieferntastern. Linnaea Entomologica, 6: 81-197.

Rudy Plarre, BAM, Unter den Eichen 87, 12205 Berlin, Germany.

E-mail: ruediger.plarre@bam.de

Bianca Krüger-Carstensen, BAM, Unter den Eichen 87, 12205 Berlin, Germany.

E-mail: bianca.krueger-carstensen@bam.de 